\title{
Saponin B, a novel cytostatic compound purified from Anemone taipaiensis, induces apoptosis in a human glioblastoma cell line
}

\author{
YUANGANG WANG $^{1 *}$, HAIFENG TANG ${ }^{2 *}$, YUN ZHANG $^{3 *}$, JUAN LI $^{1}$, BO LI ${ }^{1}$, \\ ZHENHUI GAO $^{1}$, XIAOYANG WANG ${ }^{2}$, GUANG CHENG $^{1}$ and ZHOU FEI $^{1}$ \\ ${ }^{1}$ Department of Neurosurgery, Xijing Institute of Clinical Neuroscience, Xijing Hospital, ${ }^{2}$ Department of Pharmacology, \\ Xijing Hospital, ${ }^{3}$ Department of Immunology, Fourth Military Medical University, Xi'an, Shannxi, P.R. China
}

Received June 6, 2013; Accepted September 4, 2013

DOI: $10.3892 /$ ijmm.2013.1500

\begin{abstract}
Glioblastoma multiforme (GBM) is one of the most common malignant brain tumors. Saponin B, a novel compound isolated from the medicinal plant, Anemone taipaiensis, has been found to have a strong time- and dose-dependent cytostatic effect on human glioma cells and to suppress the growth of U87MG GBM cells. In this study, we investigated whether saponin B induces the apoptosis of glioblastoma cells and examined the underlying mechanism(s) of action of saponin B. Saponin B significantly suppressed U87MG cell proliferation. Flow cytometric analysis of DNA in the U87MG cells confirmed that saponin B blocked the cell cycle at the $S$ phase. Furthermore, treatment of the U87MG cells with saponin B induced chromatin condensation and led to the formation of apoptotic bodies, as observed under a fluorescence microscope, and Annexin V/PI assay further suggested that phosphatidylserine (PS) externalization was apparent at higher drug concentrations. Treatment with saponin B activated the receptor-mediated pathway of apoptosis, as western blot analysis revealed the activation of Fas-1. Saponin B increased the Bax and caspase-3 ratio and decreased the protein expression of Bcl-2. The results from the present study demonstrate that the novel compound, saponin B, effectively induces the apoptosis of GBM cells and inhibits glioma cell growth and survival. Therefore, saponin B may be a potential candidate for the development of novel cancer therapeutics with antitumor activity against gliomas.
\end{abstract}

Correspondence to: Professor Guang Cheng or Professor Zhou Fei, Department of Neurosurgery, Xijing Institute of Clinical Neuroscience, Xijing Hosipital, Fourth Military Medical University, No. 127 Changle Western Road, Xi'an, Shannxi 710032, P.R. China

E-mail: chg16801@163.com

E-mail: feizhou@fmmu.edu.cn

"Contributed equally

Key words: apoptosis, Anemone taipaiensis, cell viability, human glioblastoma, U87MG cells, anticancer drug

\section{Introduction}

Glioblastoma is one of the most malignant human tumors (1), and despite aggressive surgical resection and radiotherapy, the median survival for patients with glioma does not normally exceed one year (2-4). Glioblastoma multiforme (GBM) is able to avoid immunosurveillance and the tumor cells proliferate extensively with strikingly high rates due to its intrinsic properties. The success of chemotherapy in patients with GBM is hampered by the issue of drug resistance, and the need for the discovery of more effective agents and therapeutic regimens to treat GBM is becoming increasingly urgent (5). Numerous plant-derived compounds, such as betulinic (6) and asiatic acids (7) have been reported to be potential anti-glioma agents, although most of these compounds are no longer considered as possible treatments for human glioma. This is due either to their modification in the liver or to their inability to pass through the blood-brain barrier.

Traditional Chinese medicinal herbs are widely known to be effective in the treatment of a number of diseases. For example, arteannuin and dihydroartemisinin tablets purified from sweet wormwood have been used to cure malaria. Examples of plant-based therapeutic anticancer drugs include camptothecin from Camptotheca acuminata, etoposide from Podophyllum peltatum, vincristine from Catharanthus roseus and paclitaxel from Taxus (yew) $(8,9)$.

Saponin B was first isolated from Anemone taipaiensis, a ferine plant of the Qinling mountains of southern Shaanxi province, China, that is distributed in the hill country of the fertile slopes or rocky grasslands at altitudes between 2,900 and 3,700 m. Wang et al isolated eight saponins from Anemone taipaiensis (10). In this study, we first investigated the effects of saponin B on the human U87MG GBM cell line, as an in vitro model to explore the effects of saponin B on GBM cell growth and apoptosis. Apoptosis is a physiological, energy-requiring process that is characterized by the formation of apoptotic bodies inside cells and seems to be genetically programmed (11). It is widely accepted that apoptosis is preferred to necrosis as a mechanism of tumor cell killing, since apoptosis does not promote inflammatory processes $(12,13)$. The demonstration of apoptotic capacity 
would therefore make this substance of interest as a potential anticancer reagent.

\section{Materials and methods}

Cell culture. The following three cell lines were obtained from the American Type Culture Collection (ATCC): ECV304 (human umbilical vein endothelial cells), U87MG and U251MG (GBM cells). Human GBM cells used in this study were grown as a monolayer culture in Dulbecco's modified Eagle's medium (DMEM; Gibco-BRL, Carlsbad, CA, USA) supplemented with $10 \%$ fetal bovine serum (Gibco-BRL) and antibiotics in a humidified atmosphere containing $5 \% \mathrm{CO}_{2}$ at $37^{\circ} \mathrm{C}$.

Drug sample. Saponin B was obtained from the Department of Pharmacology of Xijing Hospital, Fourth Military Medical University, Xi'an, China and established as $3 \beta-\mathrm{O}-\{\beta-\mathrm{D}-$ xylopyranosyl-(1-3)- $\alpha$-L-rhamnopyranosyl- $(1 \rightarrow 2)-[\beta-\mathrm{D}$-glucopyranosyl-(1 $\rightarrow 4)]-\alpha$-L-arabinopyranosyl $\}$ oleanolic acid $28-\mathrm{O}$ $\{\alpha$-L-rhamnopyranosyl-( $1 \rightarrow 4)-\beta$-D-glucopyranosyl- $(1 \rightarrow 6)-\beta$ D-glucopyranoside\}; the molecular formula was $\mathrm{C}_{70} \mathrm{H}_{114} \mathrm{O}_{34}$ (molecular weight, 1,498). The molecular structure of saponin B is shown in Fig. 1A. The purity of the sample was assessed by high-performance liquid chromatography (HPLC) as more than $95 \%$ (Fig. 1B). The reagent was placed in dimethyl sulfoxide (DMSO) and shaken until the powder dissolved, then diluted with the culture solution (DMEM). The stock solutions were stored at $4^{\circ} \mathrm{C}$ and the volume of DMSO was maintained at $<0.5 \%$ so as not to affect cell growth. The final concentration of the stock solution was confirmed at $500 \mu \mathrm{g} / \mathrm{ml}$.

3-(4,5-Dimethylthiazol-2-yl)-2,5-diphenyltetrazolium bromide (MTT) assay. Following the treatments, cell viability was examined by MTT assay. The U87MG and U251MG cells were seeded at a density of $3 \times 10^{4}$ cells/well into 96-well plates prior to drug treatment. Saponin B was added to the medium and the cells were continuously treated for $72 \mathrm{~h}$ at different concentrations (1.3-42.7 $\mu \mathrm{mol} / \mathrm{l})$, and then MTT assay was performed as previously described by Mickisch et al (14). The controls cells were incubated in control medium containing $0.1 \%$ DMSO.

Cell cycle analysis. In order to analyze the effect of saponin B on the cell cycle distribution of U87MG glioblastoma cells, flow cytometry was used to elucidate the mechanisms behind the inhibition of proliferation. The U87MG cells were trypsinized, counted, centrifuged and fixed in ethanol at certain time points after the treatment. The cells were then washed twice in phosphate-buffered saline (PBS) and centrifuged. The pellets were resuspended in a solution of ribonuclease $(0.02 \mathrm{mg} / \mathrm{ml}$, Sigma, St. Louis, MO, USA) and propidium iodide (PI; $0.02 \mathrm{mg} / \mathrm{ml}$, Sigma), and incubated at $4^{\circ} \mathrm{C}$ for $30 \mathrm{~min}$. The fluorescence of approximately 10,000-20,000 stained cells was measured. The results were expressed as a plot of fluorescence intensity vs. cell number as previously described (15).

Cellular and nuclear morphology. We determined the residual cell viability and number of apoptotic U87MG glioblastoma cells following treatment with saponin $\mathrm{B}$ at various concentrations [inhibitory concentration (IC) ${ }_{25}, \mathrm{IC}_{50}$ and $\mathrm{IC}_{75}$ ] for 8 and $24 \mathrm{~h}$.
A

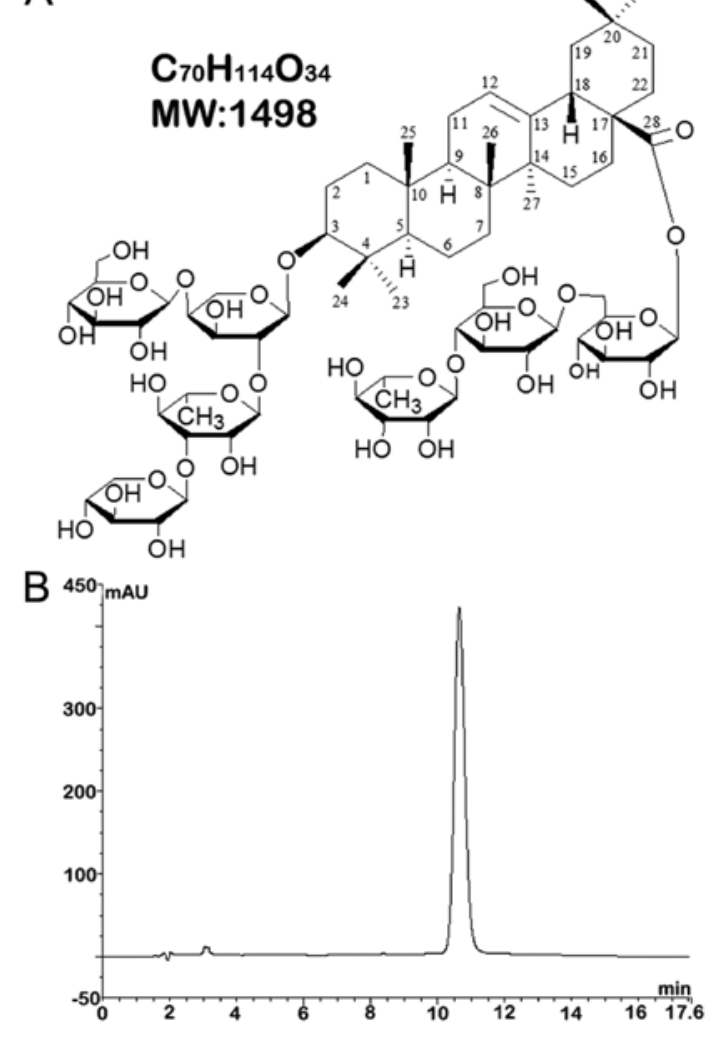

Figure 1. (A) Structure of saponin B purified from Anemone taipaiensis (B) The purity of saponin was assessed by high-performance liquid chromatography (HPLC); the chromatographic conditions were as follows: column, YMC-Pack R\&D ODS-A (5 mm, 4.6x250 mm I.D.); mobile phase, $\mathrm{MeOH}: \mathrm{H}_{2} \mathrm{O}(65: 35, \mathrm{~V} / \mathrm{V})$; flow rate, $1.0 \mathrm{ml} / \mathrm{min}$; temperature, $30^{\circ} \mathrm{C}$; detective wavelength, $206 \mathrm{~nm}$.

Apoptosis was analyzed after staining the cells with Hoechst 33342 (Sigma) at a final concentration of $1.5 \mu \mathrm{M}$ for $10 \mathrm{~min}$ and cell morphology was determined using a fluorescence microscope (Zeiss Axiovert 200; Carl Zeiss, Oberkochen, Germany). The cells were analyzed at $\mathrm{x} 40$ magnification and documented using a charge-coupled device (CCD) camera (Zeiss Axiocam MR; Carl Zeiss). We determined the number of apoptotic cells based on characteristic morphological features. The percentage of apoptotic cells was calculated from three separate experiments $(16,17)$.

Annexin V/PI staining. Fluorophore-labeled Annexin V [a protein that exhibits nanomolar affinity for phosphatidylserine (PS)] binding to externalized PS has been extensively employed as a reliable marker of apoptosis. The appearance of PS on the extracellular cell membranes was therefore evaluated with Annexin V/PI staining (18). The U87MG glioblastoma cells $\left(1 \times 10^{6}\right)$ treated as described above were washed twice in PBS, and then trypsinized with $0.13 \mathrm{~g} / 1$ trypsin in PBS-EDTA (ethylenediaminetetraacetic acid). We then terminated the trypsin reaction with culture medium containing $10 \%$ fetal bovine serum. The cells were collected, centrifuged $(5 \mathrm{~min}$, $800 \times \mathrm{g}, 4^{\circ} \mathrm{C}$ ), washed twice in ice-cold PBS and resuspended in $1 \mathrm{X}$ binding buffer $(10 \mathrm{mM}$ HEPES/NaOH, pH 7.4, $140 \mathrm{mM}$ $\mathrm{NaCl}, 2.5 \mathrm{mM} \mathrm{CaCl}_{2}$ ). Subsequently, $5 \mu \mathrm{l}$ of Annexin V-FITC (fluorescein isothiocyanate; BD Pharmingen, San Jose, CA, 


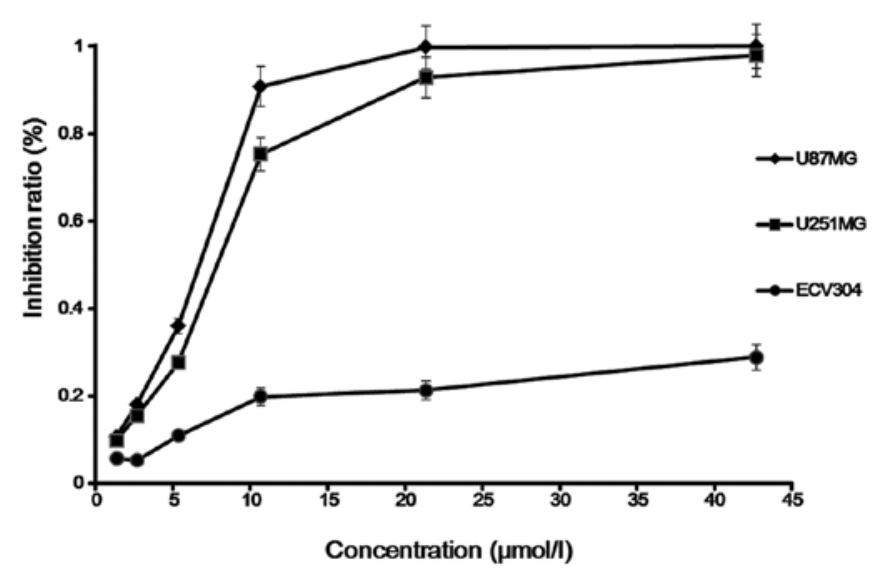

Figure 2. Cell viability was determined by MTT assay and the results revealed that saponin B exerted a dose-dependent cytostatic effect on human glioma cells (U87MG and $\mathrm{U} 251 \mathrm{MG}$ ) at $72 \mathrm{~h}$, which is only approximately $20 \%$ below the cytotoxic effect on ECV304 human umbilical vein endothelial cells at the highest concentration. The results are shown as the mean values of three experiments \pm standard deviation (SD). Based on the inhibory concentrations of saponin B [25\% ( $\left.\mathrm{IC}_{25}, 5.2 \mu \mathrm{mol} / \mathrm{l}\right), 50 \%\left(\mathrm{IC}_{50}, 6.7 \mu \mathrm{mol} / \mathrm{l}\right)$ and $75 \%\left(\mathrm{IC}_{75}\right.$, $8.7 \mu \mathrm{mol} / \mathrm{l})]$ the U87MG cells were selected to further analyze the effects of saponin B.

USA) and $10 \mu \mathrm{l}$ of PI $(50 \mu \mathrm{g} / \mathrm{ml})$ were added to the $100 \mu \mathrm{l}$ of cell suspension and incubated for $15 \mathrm{~min}$ at room temperature in the dark. Finally, $400 \mu \mathrm{l}$ of binding buffer were added to the samples, which were kept ice cold until they were analyzed on a FACSCalibur (Becton Dickinson, Franklin Lakes, NJ, USA) flow cytometer. Ten thousand cells were analyzed per sample: viable cells $\left(\mathrm{FITC}^{-} \mathrm{PI}^{-}\right)$, apoptotic cells $\left(\mathrm{FITC}^{+} / \mathrm{PI}^{-}\right.$ and $\mathrm{FITC}^{+} / \mathrm{PI}^{+}$) and necrotic cells $\left(\mathrm{FITC}^{-} / \mathrm{PI}^{+}\right)$as previously described (19-22).

Analysis of DNA fragmentation. After being treated with saponin B for the pre-determined periods of time, the cells were collected, washed and pelleted by centrifugation, and $200 \mu \mathrm{l}$ binding/lysis buffer $(20 \mathrm{ml}$ nucleic acid binding, $6 \mathrm{M}$ guanidine-HCL, $10 \mathrm{mM}$ urea, $10 \mathrm{mM}$ tris-HCL, 20\% Triton $\mathrm{X}-100, \mathrm{pH} 4.4)$ were added to $2 \times 10^{6}$ cells in a volume of $200 \mu \mathrm{l}$ and mixed immediately. The cells were then incubated for $10 \mathrm{~min}$ at $25^{\circ} \mathrm{C}, 100 \mu \mathrm{l}$ isopropanol were added and the sample was vortexed. We combined a filter tube and a collection tube and pipetted the sample. In addition, the suspension was centrifuged for $1 \mathrm{~min}$ at 8,000 rpm in a standard tabletop centrifuge. We discarded the flow through and again combined the filter tube and the used collection tube. We added $500 \mu \mathrm{l}$ washing buffer to the upper reservoir and centrifuged for $1 \mathrm{~min}$ at $8,000 \mathrm{rpm}$. We then discarded the flow through and again combined the filter tube and the used collection tube. We added $500 \mu 1$ washing buffer to the upper reservoir and centrifuged for $1 \mathrm{~min}$ at $8,000 \mathrm{rpm}$, finally centrifuging for $10 \mathrm{sec}$ at the maximum speed, 13,000 rpm, to remove the residual washing buffer. We discarded the collection tube and inserted the filter tube in a clean $1.5 \mathrm{ml}$ cup or tube, then used $200 \mu \mathrm{l}$ of pre-warmed $\left(70^{\circ} \mathrm{C}\right)$ elution buffer. We added elution buffer to the filter tube and centrifuged for $1 \mathrm{~min}$ at 8,000 rpm. Finally, following the manufacturer's instructions, the samples were loaded on $1 \%$ agarose gel, separated by electrophoresis $(50 \mathrm{~V}, 1.5 \mathrm{~h})$ and visualized by staining with ethidium bromide
(Roche, Cat. no. 11835246001, Basel, Switzerland) as previously described (23).

Western blot analysis. The activation of caspases followed by their cleavage is well known to be an important phenomenon for the induction of apoptosis (24). The Bcl-2 family, including $\mathrm{Bcl}-2, \mathrm{Bcl}-\mathrm{xL}$, Bax and Bad, regulates various steps of apoptosis. Bax and Bad promote programmed cell death, whereas Bcl-2 and Bcl-xL block cell death $(25,26)$ and the involvement of the $B c l-2$ gene in apoptosis has been reported by several studies on anticancer drugs $(27,28)$. To identify the molecular mechanisms involved in the enhanced apoptosis observed in the U87MG cells treated with saponin B, we performed immunoblot analysis to detect caspase activation using specific antibodies. The cells were treated with saponin B, incubated for 8 and $24 \mathrm{~h}$, and then collected, lysed in lysis buffer [ $150 \mathrm{mM} \mathrm{NaCl}, 1 \% \mathrm{NP}-40,0.5 \%$ sodium deoxycholate, $0.1 \%$ SDS, $50 \mathrm{mM}$ Tris- $\mathrm{HCl}, \mathrm{pH} 8.0$, $10 \mathrm{mM}$ EDTA and $1 \mathrm{mM}$ phenylmethanesulfonylfluoride (PMSF); Sigma] for $30 \mathrm{~min}$, and the cells were homogenized at $4^{\circ} \mathrm{C}$. For each sample, $30 \mu \mathrm{g}$ of protein were loaded onto a $12.5 \%$ SDS-polyacrylamide gel, electrophoresed, and transferred onto a nitrocellulose membrane $(0.22 \mu \mathrm{m}$, Schleicher \& Schuell Protran; Schleicher \& Schuell BioScience GmbH, Dassel, Germany). The membranes were blocked for $1 \mathrm{~h}$ at room temperature with a blocking buffer [Tris-buffered saline containing $0.1 \%$ Tween-20 (w/v); Sigma] and 5\% non-fat milk $(\mathrm{w} / \mathrm{v})$. Primary antibodies (applied for $1 \mathrm{~h}$ at room temperature, or overnight at $4^{\circ} \mathrm{C}$ ) were anti-Bcl-2 (rabbit monoclonal Ab-1, Oncogene Science, Cambridge, MA, USA), anti-Bax (rabbit polyclonal N-20, Santa Cruz Biotechnology, Santa Cruz, CA, USA), anti-caspase-3 (rabbit, purity $>95 \%$ ), anti-Fas-1 (rabbit, purity $>95 \%$ ), anti-actin (goat monoclonal C-2, Santa Cruz Biotechnology). All antibodies were diluted 1:1000, except for anti-actin (1:300).

\section{Results}

Cytostatic effect. Saponin B at doses ranging from 1.67 to $13.35 \mu \mathrm{mol} / 1$ exerted a significant anti-proliferative effect on the human glioblastoma cell line, as shown by time course analysis, and also exerted a strong dose-dependent cytostatic effect on human glioma cells. For the U87MG cells, the $\mathrm{IC}_{25}, \mathrm{IC}_{50}$ and $\mathrm{IC}_{75}$ of saponin $\mathrm{B}$ at $72 \mathrm{~h}$ were found to be $\mathrm{IC}_{25}, 5.2 \mu \mathrm{mol} / \mathrm{l}$; $\mathrm{IC}_{50}, 6.7 \mu \mathrm{mol} / 1$; and $\mathrm{IC}_{75}, 8.7 \mu \mathrm{mol} / 1$. For the U251MG cells, these concentrations were $\mathrm{IC}_{25}, 6.2 \mu \mathrm{mol} / 1 ; \mathrm{IC}_{50}, 7.9 \mu \mathrm{mol} / \mathrm{l}$; and $\mathrm{IC}_{75}, 10.5 \mu \mathrm{mol} / 1$. In order to clarify the mechanisms behind the inhibition of cell growth, we selected the U87MG cells as the subject for the following experiments (Fig. 2).

Cell cycle analysis. After the cells were exposed to various concentrations of saponin $\mathrm{B}\left(\mathrm{IC}_{25}, \mathrm{IC}_{50}\right.$ or $\left.\mathrm{IC}_{75}\right)$ for $24 \mathrm{~h}$, flow cytometric analysis of the PI-stained cells revealed that substantial numbers of cells accumulated in the $\mathrm{S}$ phase of the cell cycle, and that the percentage of cells in the G0/G1 phase decreased, whereas the number of cells in the $S$ and G2/M phases of the cell cycle increased. As shown in Fig. 3, saponin $\mathrm{B}\left(\mathrm{IC}_{75}\right)$ significantly increased $\mathrm{S}$ phase arrest. These results demonstrate that one mechanism by which saponin $B$ inhibits the growth of U87MG cells is through the induction of $\mathrm{S}$ phase cell cycle arrest in a dose-dependent manner (Fig. 3). 


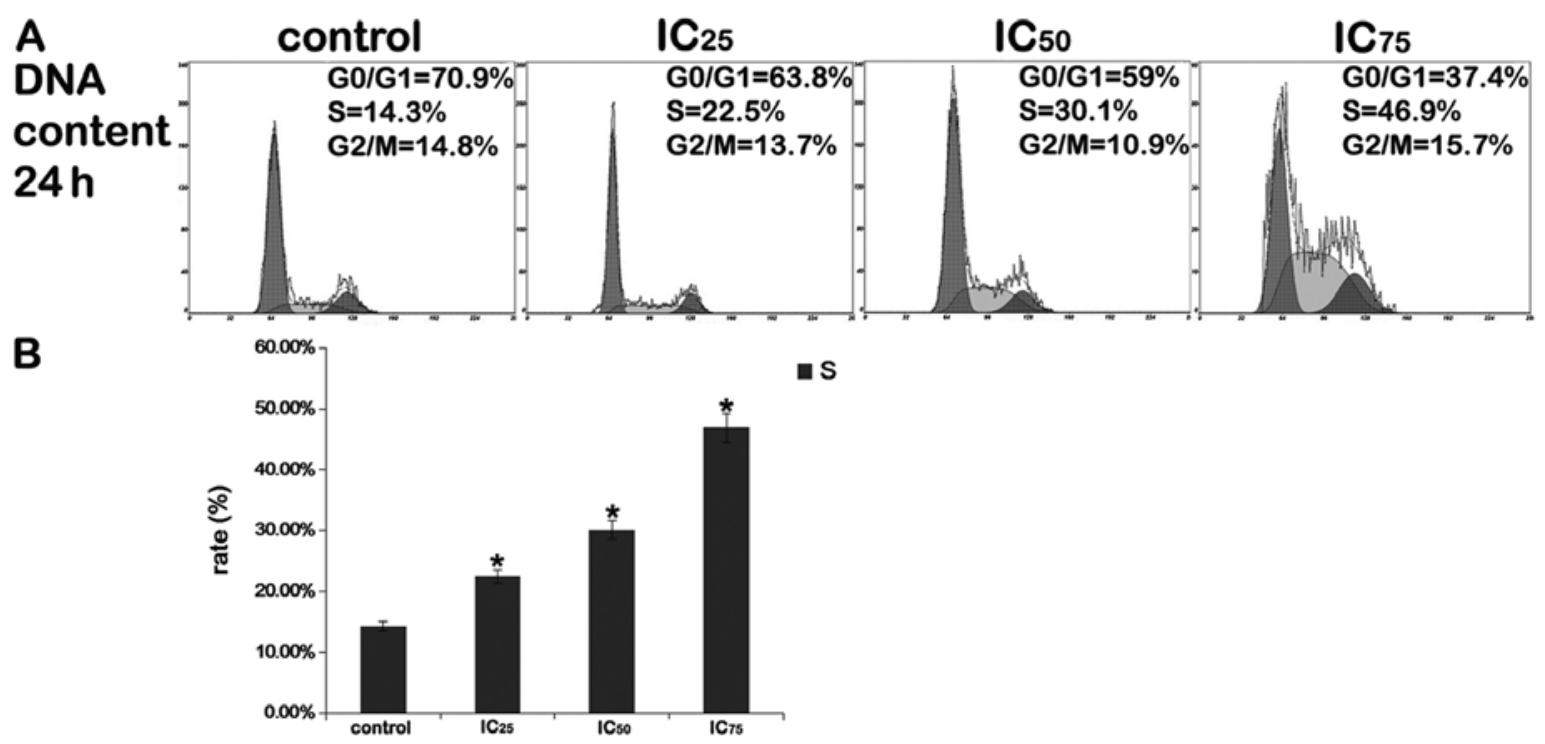

Figure 3. Changes in the cell cycle following treatment with saponin B. (A) Following treatment with various concentrations of saponin B for $24 \mathrm{~h}$, the PI-stained U87MG glioblastoma cells were analyzed by flow cytometry. The data are presented via histograms in which the cell number is plotted against the DNA content. Percentages of cells distributed in the S regions of the histograms are indicated in each histogram. (B) Each value is the mean \pm SD of three determinations. "P<0.05, Dunnett's t-test.

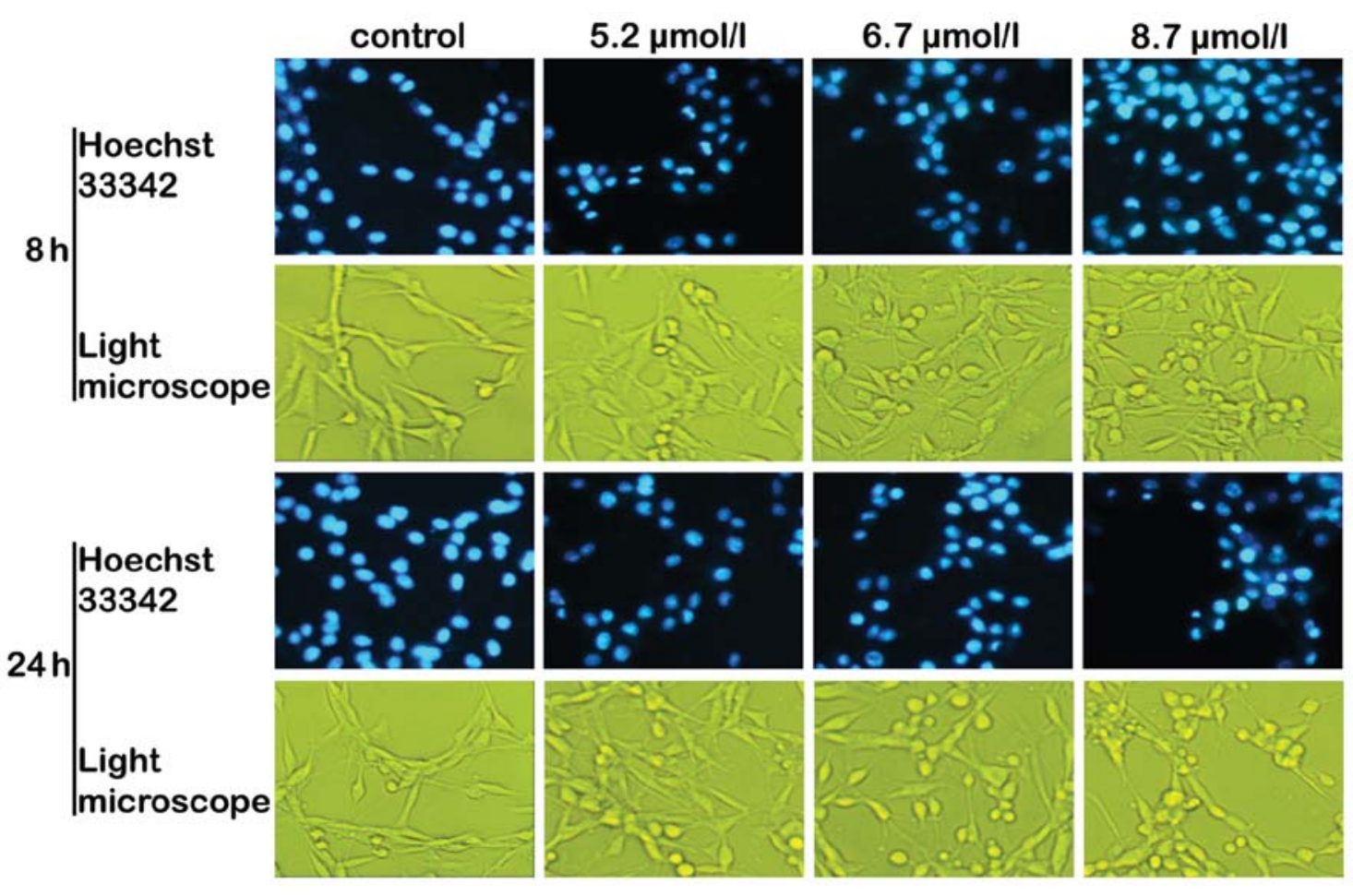

Figure 4. Determination of residual cell viability and apoptosis in U87MG glioblastoma cells following treatment with saponin B. After the U87MG cells were exposed to various concentrations of saponin $\mathrm{B}\left(\mathrm{IC}_{25}, 5.2 \mu \mathrm{mol} / 1\right.$; $\mathrm{IC}_{50}, 6.7 \mu \mathrm{mol} / 1$; and $\left.\mathrm{IC}_{75}, 8.7 \mu \mathrm{mol} / \mathrm{l}\right)$ for 8 and $24 \mathrm{~h}$, morphological changes were observed under a light microscope. The cells shrank and started to round up in proportion to the increasing concentrations and different time points. The outstanding chromatin condensation and nuclear fragmentation (nuclear condensation, boundary aggregation and split, even DNA fragmentation) for apoptosis induction were visualized under a fluorescence microscope with Hoechst 33342 staining of U87MG cells following treatment with various concentrations of saponin B $\left(\mathrm{IC}_{25}, \mathrm{IC}_{50}\right.$ and $\left.\mathrm{IC}_{75}\right)$ for 8 and $24 \mathrm{~h}$.

Cellular and nuclear morphology. Chromatin condensation and nuclear fragmentation, typical of the induction of apoptosis, were observed under a fluorescence microscope using Hoechst 33342 staining. Saponin B induced the characteristic morphological features of apoptosis, including cell shrinkage with condensation of the cytoplasm, membrane blebbing and the formation of apoptotic bodies (Fig. 4). Under a light microscope, with increasing concentrations of saponin $\mathrm{B}$, the cells were increasingly found in rounded form (Fig. 4). Three different types of changes were observed: i) weak and irregu- 

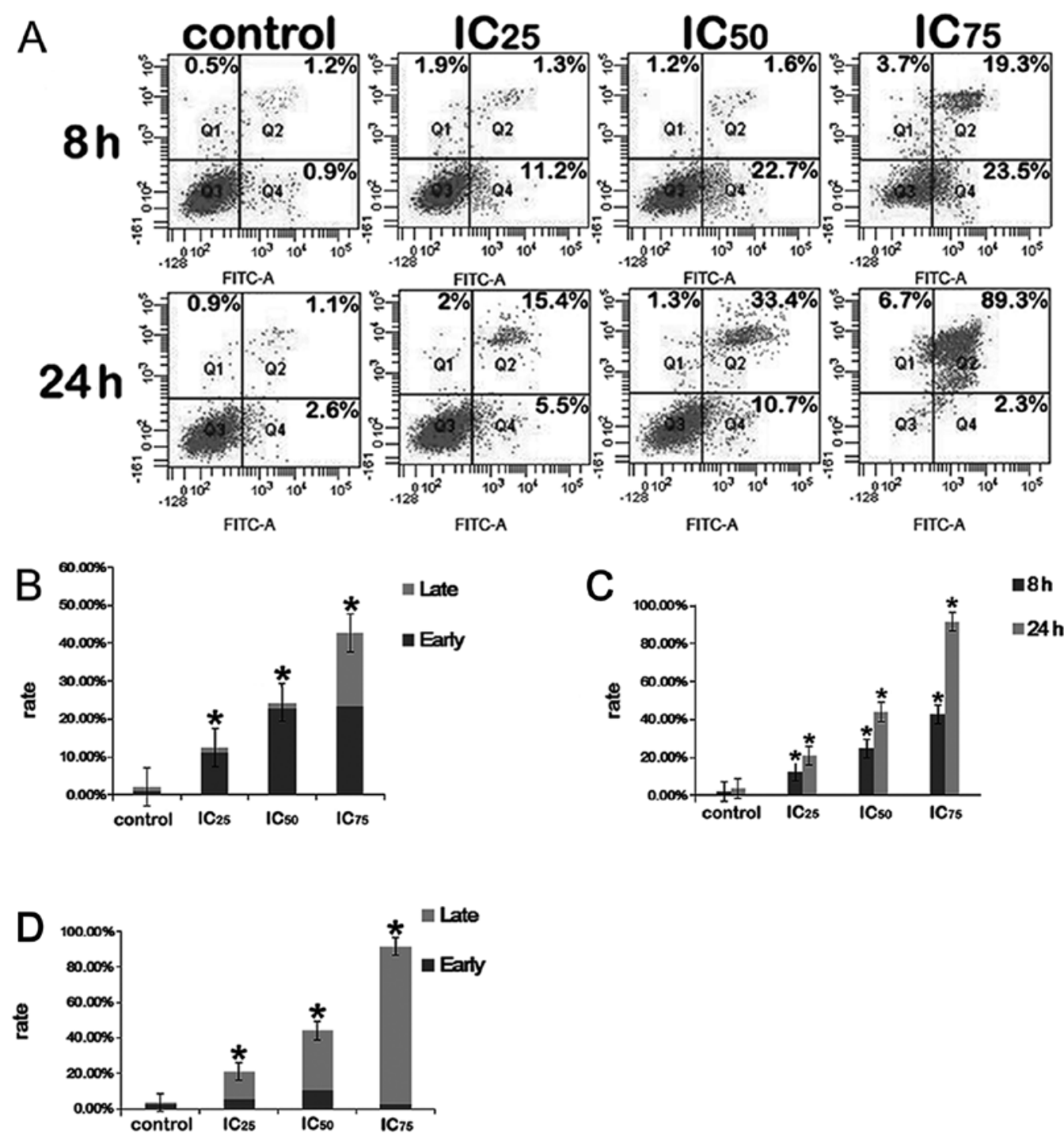

Figure 5. (A) Analysis of U87MG cells by flow cytometry demonstrated the transition of cells through an apoptotic phase in response to treatment with saponin B. The U87MG cells were exposed to various reagent concentrations (5.2, 6.7 and $8.7 \mu \mathrm{mol} / \mathrm{l})$ for 8 and $24 \mathrm{~h}$. Phosphatidylserine (PS) externalization was determined by a combined Annexin V/PI dual staining assay. Necrotic cells are Annexin $\mathrm{V}^{-} / \mathrm{PI}^{+}$, healthy cells are Annexin $\mathrm{V}^{-} / \mathrm{PI}^{-}$, early apoptotic cells are Annexin $\mathrm{V}^{+} / \mathrm{PI}$, and late apoptotic cells are Annexin $\mathrm{V}^{+} / \mathrm{PI}^{+}$. Percentages are displayed in the homologous panel. (B) Effect of saponin $\mathrm{B}$ on the apoptosis of U87MG glioblastoma cells at $8 \mathrm{~h}$. ${ }^{*} \mathrm{P}<0.05$, Dunnett's t-test. (C) Early and late apoptosis of U87MG cells at $8 \mathrm{~h}$ compared with $24 \mathrm{~h}$. ${ }^{*} \mathrm{P}<0.05$, paired samples t-test. (D) Effect of saponin B on the apoptosis of U87MG cells at $24 \mathrm{~h} .{ }^{*} \mathrm{P}<0.05$, Dunnett's t-test.

larly shaped marginal chromatin condensation; ii) highly condensed nuclear chromatin that was inverted on one side; iii) relatively compact and irregularly shaped marginal chromatin condensation, characteristics of apoptosis $(29,30)$.

Annexin V-PI dual staining. In the present study, we investigated the effects of saponin B on the apoptosis of U87MG glioblastoma cells. Fluorophore-labeled Annexin V (a protein that exhibits nanomolar affinity for OS) binding to externalized PS has been extensively employed as a reliable marker of apoptosis (31). To establish whether such processes were induced due to treatment with saponin B, the U87MG cells were exposed to various reagent concentrations $(5.2,6.7$ and $8.7 \mu \mathrm{mol} / \mathrm{l}$ ) for 8 and $24 \mathrm{~h}$. As shown in Fig. 5, the untreated control cells showed few or no apoptotic cells, whereas apoptosis was markedly induced by saponin B compared with the untreated controls.
DNA fragmentation. As shown in Fig. 6B, the untreated control group showed few or no apoptotic cells, whereas apoptosis was markedly induced by saponin B. To further confirm that saponin B induced apoptosis, a DNA fragmentation assay was performed. After the U87MG cells were treated for $24 \mathrm{~h}$ with saponin B, cellular DNA revealed a distinctive ladder pattern of DNA cleavage in the apoptotic U87MG cells.

Western blot analysis. The Bax, caspase- 3 and Fas-1 proteins were upregulated in the treated groups following exposure to saponin $\mathrm{B}$, and the expression levels of a typical pro-survival protein (Bcl-2) were downregulated by saponin B (Fig. 6A, C and $\mathrm{D}) . \beta$-actin expression was monitored to ensure that an equal amount of protein was loaded in each lane. Monitoring revealed the expression of pro-apoptotic proteins (caspase-3, Bax and Fas-1) in a dose-dependent manner, and timedependence was shown by comparison between the 8 and $24 \mathrm{~h}$ 

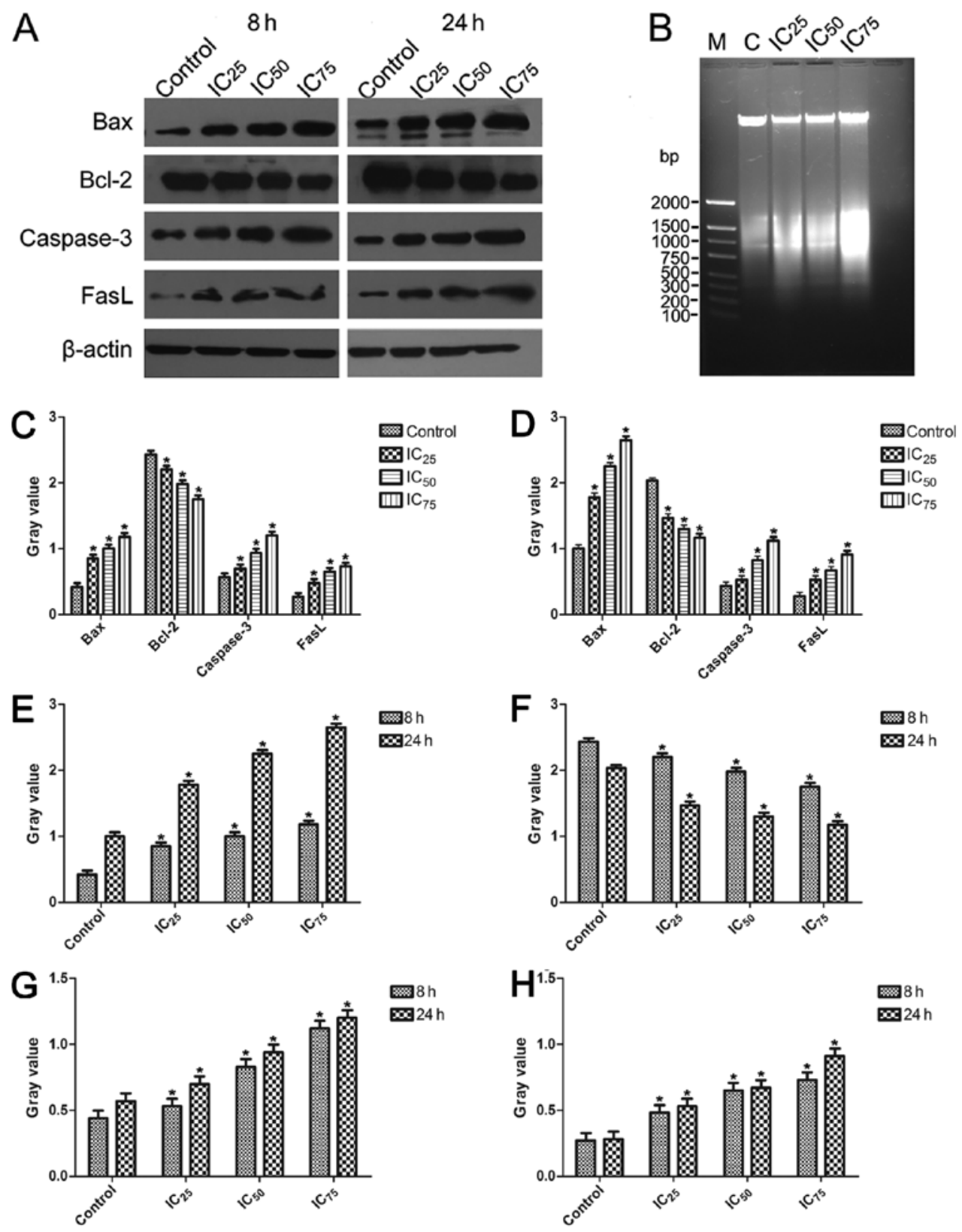

Figure 6. (A) Western blot analsyis was used to examine the activation of the intrinsic pathway of apoptosis in U87MG glioblastoma cells. (B) Approximately $1 \times 10^{6}$ U87MG cells were treated and cultured for $24 \mathrm{~h}$ with various concentrations of saponin B. Isolated DNA was analyzed using $1 \%$ agarose gel electrophoresis. (C) After the U87MG cells were treated for $8 \mathrm{~h}$, the ratios for Bax, Bcl-2, caspase-3 and Fas-1 were examined at different concentrations. All data are presented as the means $\pm \mathrm{SE}$ of triplicate experiments relative to the control, ${ }^{*} \mathrm{P}<0.05$, Dunnett's t-test. (D) After the U87MG cells were treated for $24 \mathrm{~h}$, the ratios for Bax, Bcl-2, caspase-3 and Fas-1 were examined at different concentrations. " $\mathrm{P}<0.05$, Dunnett's t-test. (E) Bar graph represents the relative expression of the Bax ratio calculated from each group. ${ }^{*} \mathrm{P}<0.05$, paired-samples t-test. $(\mathrm{F})$ Bar graph represents the relative expression of the Bcl-2 ratio calculated from each group. " $\mathrm{P}<0.05$, paired samples t-test. $(\mathrm{G})$ Bar graph represents the relative expression of the caspase- 3 ratio calculated from each group. ${ }^{*} \mathrm{P}<0.05$, paired samples t-test. (H) Bar graph represents the relative expression of the Fas-l ratio calculated from each group. "P<0.05, paired samples t-test.

observations (Fig. 6E, G and H). The decreased expression of Bcl-2 was observed (Fig. 6F).

\section{Discussion}

GBM, which is categorized amongst the tumors with the greatest angiogenic ability and occurs more frequently than other types of primary tumors of the central nervous system, is a highly vascularized and invasive malignant tumor with poor clinical outcomes. Even after optimal aggressive surgery, radiation and chemotherapy treatments, the mean reported survival rate is less than one year (32). Traditional Chinese medicinal herbs are widely known to be effective in the treatment of several diseases. It has been reported that among the 155 small molecular antitumor drugs developed from the 1940s to June $2006,47 \%$ are natural compounds or are directly derived from natural compounds (33); thus, the development of chemopreventive agents derived from Chinese medicinal herbs is an important area of cancer research.

The present study demonstrates the potent and selective cytostatic effects of saponin B in a panel of U87MG GBM cell lines. We demonstrate that saponin B exerts a strong time- and 
dose-dependent growth inhibitory effect on highly malignant human glioma cell lines, an effect that was confirmed by an MTT assay. The antitumor effects of saponin B may result from multiple mechanisms of action, such as interfering with cell cycle progression and inducing apoptosis.

Mammalian cells have evolved a complex defense network to maintain genomic integrity by inhibiting the fixation of permanent damage. Cell cycle checkpoints prevent cells with damaged genomes from undergoing DNA replication or mitosis (34). The control of the cell cycle progression in cancer cells is a potentially effective strategy for controling tumor growth (35). In the study by Zhou et al, using flow cytometric analysis of DNA in U87MG cells, the authors demonstrated that novaeguinoside II induced the prominent appearance of an $\mathrm{S}$ phase peak in the cell cycle (36). Therefore, in this study, we analyzed the effects of saponin B on the cell cycle distribution of U87MG glioblastoma cells in order to elucidate the mechanisms behind the inhibition of proliferation. Our data indicated that exposure to saponin $\mathrm{B}$ resulted in an increased $S$ phase arrest in the GBM cells, which suggests that DNA synthesis was inhibited by saponin B.

Following exposure to saponin B, apoptotic cells aggregated, shrank and detached from the surface of the culture flask. Hoechst 33342 staining of the nuclei revealed fragmented nuclei in the treated cells. The classical alterations of apoptosis were more distinct in the $24 \mathrm{~h}$-treated group than those of the 8 h-treated group. These results were consistent with the changes observed under a light microscope. This observation confirmed the data obtained by Annexin V/PI assay.

When the U87MG cells were exposed to 5.2, 6.7 and $8.7 \mu \mathrm{mol} / 1$ saponin $\mathrm{B}$ for 8 and $24 \mathrm{~h}$, the apoptotic ratio was proportional to the concentration and treatment time. Annexin V/PI assay suggested that PS externalization was apparent at the higher drug concentrations. A significant induction of apoptosis following treatment with saponin B demonstrated its anticancer effects on GBM cell lines. The results were consistent with the biochemical characteristics of apoptosis that PS externalization is an early and sensitive event during the cascade of apoptosis (37). Taken together, our data demonstrate that the potent effects of saponin B on apoptosis and cell cycle progression indicate that saponin B is able to trigger different signal transduction pathways and to exert effects on two key processes in glioma cells.

Treatment of the GBM cells with saponin B triggered an intrinsic caspase cascade due to an increase in the Bax:Bcl-2 ratio. Bax and $\mathrm{Bcl}-2$ have been reported to play a dominating role in determining whether cells die or survive (38). The Bcl-2 family members are characterized by containing at least one of four Bcl-2 homology domains (BH1-BH4) and play important roles in regulating apoptosis (39). The increased expression of Bax can induce apoptosis through the release of cytochrome $c$ from the mitochondria, while $\mathrm{Bcl}-2$ protects cells from apoptosis through teh stabilization of the mitochondrial membrane potential (40). As described above, our results suggest that saponin B is a potent compound, exerting apoptotic effects on tumor cells. Several studies have revealed that apoptosis induced by saponin is modulated through a mitochondrialdependent pathway, which was ascertained in our study by the upregulated Bax protein and downregulated Bcl-2 protein expression.
Furthermore, we employed western blot analysis to elucidate the involvement of the Fas-l protein in saponin B-mediated apoptosis in U87MG cells. It is widely known that the Fas-1/ Fas-signaling-mediated death receptor apoptotic pathway is a potential target of antitumor therapy (41); thus, targeting the death receptor pathway may provide more significant benefits for U87MG GBM cells. Our results testified that the Fas-1/Fas-signaling pathway played a crucial role in saponin B-induced apoptosis. As is also widely known, caspase- 3 activation plays a key role in the execution phase of apoptosis and is often preceded by Bcl-2, Bax and caspase-9, via the mitochondrial pathway (42), and has been identified as being a key mediator of apoptotic events in either cancerous or non-cancerous mammalian cells, such as neuronal cells and GBM cells (43). Therefore, caspase-3 is ascertained to be a common executive proteolytic enzyme in both the extrinsic and intrinsic apoptotic pathways. In this sudy, we examined the increase in active caspase- 3 fragments and caspase- 3 activity following treatment with saponin B. Saponin B was most effective in increasing caspase-3 activation and activity after 8 and $24 \mathrm{~h}$ of treatment.

Collectively, our data suggest that saponin B exerts a strong time- and dose-dependent apoptotic effect on highly malignant human glioma cell lines, rapidly inducing apoptosis through the activation of both the death receptor-mediated and mitochondrial-mediated proteolytic pathways in U87MG cells. A better understanding of the mechanisms behind the chemotherapeutic activity of saponin B would benefit future animal experiments and clinical studies, thereby increasing the prospects for the clinical treatment of this highly malignant tumor.

\section{Acknowledgements}

The authors would like to thank Xiaoyan Chen for her excellent technical assistance. This study was supported by grants from the National Natural Science Foundation of China (nos. 30873402 and 81274029) and the Natural Science Foundation of Shaanxi Province (no. 2012JM4010).

\section{References}

1. DeAngelis LM: Brain tumors. N Engl J Med 344: 114-123, 2001.

2. Stupp R, Mason WP, van den Bent MJ, Weller M, Fisher B, Taphoorn MJ, Belanger K, Brandes AA, Marosi C, Bogdahn U, Curschmann J, Janzer RC, Ludwin SK, Gorlia T, Allgeier A, Lacombe D, Cairncross JG, Eisenhauer E and Mirimanoff RO: Radiotherapy plus concomitant and adjuvant temozolomide for glioblastoma. N Engl J Med 352: 987-996, 2005.

3. Ballman KV, Buckner JC, Brown PD, Giannini C, Flynn PJ, LaPlant BR and Jaeckle KA: The relationship between six-month progression-free survival and 12-month overall survival end points for phase II trials in patients with glioblastoma multiforme. Neuro Oncol 9: 29-38, 2007.

4. Lamborn KR, Yung WK, Chang SM, Wen PY, Cloughesy TF, DeAngelis LM, Robins HI, Lieberman FS, Fine HA, Fink KL, Junck L, Abrey L, Gilbert MR, Mehta M, Kuhn JG, Aldape KD, Hibberts J, Peterson PM and Prados MD: Progression-free survival: an important end point in evaluating therapy for recurrent high-grade gliomas. Neuro Oncol 10: 162-170, 2008.

5. Curtin JF, King GD, Candolfi M, Greeno RB, Kroeger KM, Lowenstein PR and Castro MG: Combining cytotoxic and immune-mediated gene therapy to treat brain tumors. Curr Top Med Chem 5: 1151-1170, 2005.

6. Fulda S, Jeremias I, Steiner HH, Pietsch T and Debatin KM: Betulinic acid: a new cytotoxic agent against malignant braintumor cells. Int J Cancer 82: 435-441, 1999. 
7. Lee YS, Jin DQ, Kwon EJ, Park SH, Lee ES, Jeong TC, Nam DH, Huh K and Kim JA: Asiatic acid, a triterpene, induces apoptosis through intracellular $\mathrm{Ca}^{2+}$ release and enhanced expression of p53 in HepG2 human hepatoma cells. Cancer Lett 186: 83-91, 2002.

8. Cragg GM and Newman DJ: Plants as a source of anti-cancer agents. J Ethnopharmacol 100: 72-79, 2005.

9. Gordaliza M: Natural products as leads to anticancer drugs. Clin Transl Oncol 9: 767-776, 2007.

10. Wang XY, Chen XL, Tang HF, Gao H, Tian XR and Zhang PH: Cytotoxic triterpenoid saponins from the rhizomes of Anemone taipaiensis. Planta Med 77: 1550-1554, 2011.

11. Geske FJ and Gerschenson LE: The biology of apoptosis. Hum Pathol 32: 1029-1038, 2001.

12. Kumar R, Herbert PE and Warrens AN: An introduction to death receptors in apoptosis. Int J Surg 3: 268-277, 2005.

13. Abd-Elrahman I, Hershko K, Neuman T, Nachmias B, Perlman R and Ben-Yehuda D: The inhibitor of apoptosis protein Livin (ML-IAP) plays a dual role in tumorigenicity. Cancer Res 69: 5475-5480, 2009.

14. Mickisch G, Fajta S, Keilhauer G, Schlick E, Tschada R and Alken P: Chemosensitivity testing of primary human renal cell carcinoma by a tetrazolium based microculture assay (MTT). Urol Res 18: 131-136, 1990.

15. Vindelov L and Christensen IJ: An integrated set of methods for routine flow cytometric DNA analysis. Methods Cell Biol 33 127-137, 1990.

16. Scaife RM: G2 cell cycle arrest, down-regulation of cyclin B, and induction of mitotic catastrophe by the flavoprotein inhibitor diphenyleneiodonium. Mol Cancer Ther 3: 1229-1237, 2004.

17. Handrick R, Rudner J, Muller I, Eibl H, Belka C and Jendrossek V: Bcl-2 mediated inhibition of erucylphosphocholine-induced apoptosis depends on its subcellular localisation. Biochem Pharmacol 70: 837-850, 2005.

18. Narayan P, Mentzer RJ and Lasley RD: Annexin V staining during reperfusion detects cardiomyocytes with unique properties. Am J Physiol Heart Circ Physiol 281: H1931-H1937, 2001.

19. Huigsloot M, Tijdens IB, Mulder GJ and van de Water B Differential regulation of doxorubicin-induced mitochondrial dysfunction and apoptosis by Bcl-2 in mammary adenocarcinoma (MTLn3) cells. J Biol Chem 277: 35869-35879, 2002.

20. Malerba I, Gribaldo L, Diodovich C, Carloni M, Meschini R, Bowe $\mathrm{G}$ and Collotta A: Induction of apoptosis and inhibition of telomerase activity in human bone marrow and HL-60 p53 null cells treated with anti-cancer drugs. Toxicol In Vitro 19: 523-532, 2005.

21. Cheng G, Zhang X, Tang HF, Zhang Y, Zhang XH, Cao WD, Gao DK, Wang XL and Jin BQ: Asterosaponin 1, a cytostatic compound from the starfish Culcita novaeguineae, functions by inducing apoptosis in human glioblastoma U87MG cells. J Neurooncol 79: 235-241, 2006.

22. Xiao XY, Hao M, Yang XY, Ba Q, Li M, Ni SJ, Wang LS and Du X: Licochalcone A inhibits growth of gastric cancer cells by arresting cell cycle progression and inducing apoptosis. Cancer Lett 302: 69-75, 2011.

23. Ha ES, Lee EO, Yoon TJ, Kim JH, Park JO, Lim NC, Jung SK, Yoon BS and Kim SH: Methylene chloride fraction of Spatholobi Caulis induces apoptosis via caspase dependent pathway in U937 cells. Biol Pharm Bull 27: 1348-1352, 2004.

24. Edinger AL and Thompson CB: Death by design: apoptosis, necrosis and autophagy. Curr Opin Cell Biol 16: 663-669, 2004.
25. Sperandio S, de Belle I and Bredesen DE: An alternative, nonapoptotic form of programmed cell death. Proc Natl Acad Sci USA 97: 14376-14381, 2000.

26. Zhai D, Jin C, Huang Z, Satterthwait AC and Reed JC: Differential regulation of Bax and Bak by anti-apoptotic Bcl-2 family proteins Bcl-B and Mcl-1. J Biol Chem 283: 9580-9586, 2008.

27. Rega MF, Leone M, Jung D, Cotton NJ, Stebbins JL and Pellecchia M: Structure-based discovery of a new class of Bcl-xL antagonists. Bioorg Chem 35: 344-353, 2007.

28. Tse C, Shoemaker AR, Adickes J, Anderson MG, Chen J, Jin S, Johnson EF, Marsh KC, Mitten MJ, Nimmer P, Roberts L, Tahir SK, Xiao Y, Yang X, Zhang H, Fesik S, Rosenberg SH and Elmore SW: ABT-263: a potent and orally bioavailable Bcl-2 family inhibitor. Cancer Res 68: 3421-3428, 2008.

29. Leist M and Jaattela M: Four deaths and a funeral: from caspases to alternative mechanisms. Nat Rev Mol Cell Biol 2: 589-598, 2001.

30. Lovborg H, Nygren P and Larsson R: Multiparametric evaluation of apoptosis: effects of standard cytotoxic agents and the cyanoguanidine CHS 828. Mol Cancer Ther 3: 521-526, 2004.

31. Narayan P, Mentzer RJ and Lasley RD: Annexin V staining during reperfusion detects cardiomyocytes with unique properties. Am J Physiol Heart Circ Physiol 281: H1931-H1937, 2001.

32. Kaur B, Tan C, Brat DJ, Post DE and Van Meir EG: Genetic and hypoxic regulation of angiogenesis in gliomas. J Neurooncol 70: 229-243, 2004.

33. Newman DJ and Cragg GM. Natural products as sources of new drugs over the last 25 years. J Nat Prod 70: 461-477, 2007.

34. Shackelford RE, Kaufmann WK and Paules RS: Cell cycle control, checkpoint mechanisms, and genotoxic stress. Environ Health Perspect 107 (Suppl 1): 5-24, 1999.

35. Mork CN, Faller DV and Spanjaard RA: A mechanistic approach to anticancer therapy: targeting the cell cycle with histone deacetylase inhibitors. Curr Pharm Des 11: 1091-1104, 2005.

36. Zhou J, Cheng G, Cheng G, Tang HF and Zhang X: Novaeguinoside II inhibits cell proliferation and induces apoptosis of human brain glioblastoma U87MG cells through the mitochondrial pathway. Brain Res 1372: 22-28, 2011.

37. Lee SH, Meng XW, Flatten KS, Loegering DA and Kaufmann SH: Phosphatidylserine exposure during apoptosis reflects bidirectional trafficking between plasma membrane and cytoplasm. Cell Death Differ 20: 64-76, 2013.

38. Korsmeyer SJ, Shutter JR, Veis DJ, Merry DE and Oltvai ZN: Bcl-2/Bax: a rheostat that regulates an anti-oxidant pathway and cell death. Semin Cancer Biol 4: 327-332, 1993.

39. Juin P, Geneste O, Raimbaud E and Hickman JA: Shooting at survivors: Bcl-2 family members as drug targets for cancer. Biochim Biophys Acta 1644: 251-260, 2004.

40. Cory S and Adams JM: The Bcl2 family: regulators of the cellular life-or-death switch. Nat Rev Cancer 2: 647-656, 2002.

41. Ziegler DS and Kung AL: Therapeutic targeting of apoptosis pathways in cancer. Curr Opin Oncol 20: 97-103, 2008.

42. Kleibl Z, Raisová M, Novotný J, Pohlreich P and Matous B: Apoptosis and its importance in the development and therapy of tumors (review). Sb Lek 103: 1-13, 2002 (In Czech).

43. Sulejczak D, Grieb P, Walski M and Frontczak-Baniewicz M: Apoptotic death of cortical neurons following surgical brain injury. Folia Neuropathol 46: 213-219, 2008. 